\title{
呼び水式階段魚道における問題点と \\ その対処法について \\ A STUDY ON ISSUES AND COPING METHODS \\ IN THE POOL-AND-WEIR-FISHWAY WITH PRIMING WATER
}

\author{
小坂祐樹 1 ・青木宗之 2 ・田口裕基 3 - 福井吉孝 4 \\ Yuki KOSAKA, Muneyuki AOKI, Yuki TAGUCHI and Yoshitaka FUKUI \\ 1 学生員 東洋大学大学院 工学研究科環境・デザイン専攻（テ350-8585 埼玉県川越市鯨井2100） \\ 2正会員＼cjkstart博(工) パシフィックコンサルタンツ株式会社＼cjkstart河川部（テ163-6018 新宿区西新宿6-8-1） \\ 3 非会員 東洋大学 工学部環境建設学科（广350-8585 埼玉県川越市鯨井2100） \\ 4正会員 工博 東洋大学教授 理工学部都市環境デザイン学科（テ350-8585 埼玉県川越市鯨井2100）
}

\begin{abstract}
Through the ages, the pool-and-weir-fishway have been installed in many rivers in Japan. As time advances, fish-ways fail to function adequately because they are deteriorated, broken or changed flow in the downstream.

The main purpose of this study is to make clear the problems of fish-ways and to find better resolution methods to solve it. Therefore, we carried out the model experiment by using the open channel where a pool-and-weir-fish way had been set up.

As a result, a promising method to cope with the local scouring and circulation flow at the downstream of fish-way is studied by the model experiment.
\end{abstract}

Key Words : pool-and-weir-fishway, priming water, Tribolodon hakonensis, division wall, fish behavior

\section{1. はじめに}

我が国の魚道には，十分に機能していない魚道が数 多く存在している．例えば，魚道から流出する流れに より魚道下流域の河床が洗掘され，魚道下流端の隔壁 と魚道直下との水面間に大きな落差が生じていること である ${ }^{1,2)}$. この場合, 流出水脈が剥離するため魚類は 跳躍しなければならず, 魚道機能低下の原因となり, 問題となっている ${ }^{1,3)}$. しかし, 魚道下流域の河床洗掘 についての研究報告は棚田式魚道工についてのみであ $り^{4)}$ ，階段式魚道からの落下流による洗掘への影響につ いては明らかにされていない. 青木らは, 階段式魚道 の遡上効果を増進させる呼び水水路の効果について研 究を行ってきた ${ }^{7,8)}$. この呼び水水路から流出する呼び 水は, 魚道越流流速の 2 倍以上とすることが設計上の留 意点となっている ${ }^{1,2)}$. そのため, 呼び水の強い流れが 魚道下流域の洗掘をより進行させ，落差が拡大する可 能性が考えられる. したがって, 階段式魚道において も洗掘への影響を明らかにする必要があると考える.
階段式魚道は, 我が国の既設魚道の約 $90 \%$ 以上を占 めているといわれており ${ }^{5)}$ ，魚道下流入口への集魚を目 的として，呼び水水路が併設されることが多い，呼び 水水路から流出する呼び水には，1)魚道下流入口の流れ の影響範囲の拡大と，2)魚を魚道下流入口へ誘導寸る機 能がある．これは，魚が持つ走流性を利用したもので ある。しかし，呼び水により，魚道下流域に循環流が 発生する可能性がある ${ }^{5,6}$. 循環流が生じると魚はその 流れに乗ってその場に滞留してしまいブ, 魚道下流入口 を見つけることが困難になってしまう．

青木らは, 呼び水式魚道のつくり出寸魚道下流域の 流況が，魚類の行動に及ぼす影響について模型実験で の研究を行い，以下のことを明らかにしている. (1)呼 び水には集魚効果が有り, $v_{p} / v_{f}=3$ のとき最も効果が高 い $\left(v_{p} \text { : 呼び水流速, } v_{f} \text { : 魚道越流流速 }\right)^{8)}$. (2)循環流の 形成条件は模型水路での実験では， $v_{p} / v_{m} \geqq 5 （ v_{p}$ : 呼び 水流速, $v_{m}$ : 主水路流速) ${ }^{7)}$, 平行流水路を用いた実験

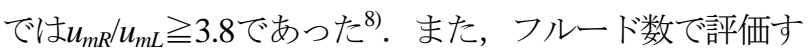
ると $F r_{R} / F r_{L} \geqq 3.59$ である ${ }^{8)}$.ここで，添字 $R ， L$ はそれぞ れ平行流水路右岸側, 左岸側を表す. (3)呼び水水路と 
$50(\mathrm{~cm}) 50(\mathrm{~cm}) 50(\mathrm{~cm}) 50(\mathrm{~cm}) 50(\mathrm{~cm})$

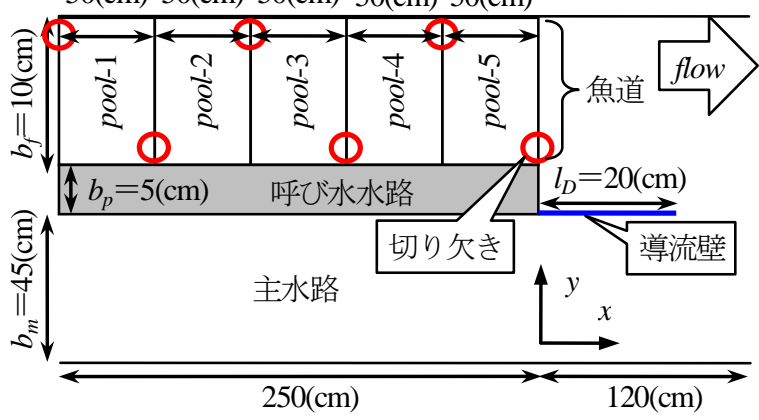

a) 平面図

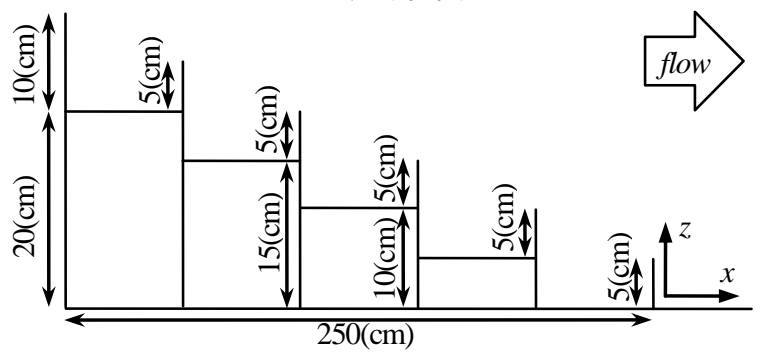

b) 側面図

図-1 階段式魚道モデル図

主水路間に導流壁を設けることで，循環流の発生を抑 制し，呼び水の集魚効果を増進することができる.

本研究では，主水路幅を $45(\mathrm{~cm})$ に拡幅した階段式魚道 を用いて, 呼び水のつくり出す魚道下流域の流れと魚 の行動特性について，更に詳細な検討を行う事を目的 としている. とくに, 魚道下流域の河床変動と魚の行 動域ついても着目し, 下流の河床変動, 流れの変化に よってもたらせられる魚道の機能低下防止法について 検討するため, 模型実験（固定床，移動床）および実 魚を用いた挙動実験, 数值解析を行った.

\section{2. 模型実験}

実験に用いた階段式魚道モデルを図-1に示す。魚道 勾配および呼び水水路勾配はそれぞれ1/10であり，隔壁 には交互に切り欠きを配置した。 導流壁は魚道と平行 に設け，導流壁長さ $l_{D}$ が魚道幅 $b_{f}$ の2倍の場合に最も効果 が発揮されるため ${ }^{7)}, l_{D} / b_{f}=2$ とした.

\section{（1）水理実験}

水理量の測定は，二次元電磁流速計（KENEK製， VM2001）を使用し, 流速の測定を行った. 1測点毎に 2048個のデータをサンプリング周波数100(Hz)で採取し， 単純平均した。 なお, 実魚の遊泳深度が水路底面付近 であるため, 水深方向の測点は $z=2(\mathrm{~cm})$ とした ${ }^{2)}$.

\section{（2）実魚を用いた挙動実験}

実魚としてウグイ(Tribolodon hakonensis)を用いた. ウ グイはほぼ全国に分布し，アユ(Plecoglossus altivelis)と
表-1 実験ケース

\begin{tabular}{|c|c|c|c|c|c|}
\hline ケース名 & $\begin{array}{c}\text { 全流量 } \\
Q(1 / \mathrm{s})\end{array}$ & $\begin{array}{c}\text { 呼び水 } \\
\text { 水路 }\end{array}$ & $l_{D} / b_{f}$ & $\begin{array}{c}\text { 河床 } \\
\text { 条件 }\end{array}$ & プール数 \\
\hline Run 1-1-A & 5.0 & 有り & 2 & 固定床 & 5 \\
\hline Run 2-1-A & 6.0 & 有り & 2 & 固定床 & 5 \\
\hline Run 3-1-A & 7.0 & 有り & 2 & 固定床 & 5 \\
\hline Run 4-1-A & 8.0 & 有り & 2 & 固定床 & 5 \\
\hline Run 5-1-A & 18.0 & 有り & 2 & 固定床 & 5 \\
\hline Run 2-2-A & 6.0 & 有り & 0 & 固定床 & 5 \\
\hline Run 4-2-A & 8.0 & 有り & 0 & 固定床 & 5 \\
\hline Run 5-2-A & 18.0 & 有り & 0 & 固定床 & 5 \\
\hline Run 2-1-B & 6.0 & 有り & 2 & 移動床 & 5 \\
\hline Run 2-2-B & 6.0 & 有り & 0 & 移動床 & 5 \\
\hline Run 2-3-B & 6.0 & 無し & 0 & 移動床 & 5 \\
\hline Run 2-4-B & 6.0 & 無し & 0 & 移動床 & 4 \\
\hline
\end{tabular}

同様に強い走流性を持っていることが知られている. 実験には平均体長 $B L=8.3(\mathrm{~cm})$ の個体を用いた。実験手 順は，階段式魚道モデル下流 $(x=250 \sim 300(\mathrm{~cm})$ ) に仕切 りを設け，その中で30分間ウグイを流れに慣れさせた. その後仕切りを取り, ウグイの挙動をビデオカメラで 撮影した．1回の実験に使用した個体数は20であり，ウ グイの学習能力を考慮し毎回異なる個体を用いた。

\section{（3）移動床実験}

一様粒径の中礫（平均粒径 $d_{50}=6.2(\mathrm{~mm})$ ) を水路に $3(\mathrm{~cm})$ の厚さで敷き均し, 流量 $Q=6(1 / \mathrm{s})$ の条件で30分間通 水を行い洗掘の様子を観察した。 その後，ポイント ゲージを用い魚道下流域 $(x=0 \sim 120(\mathrm{~cm}))$ で河床高の測 定を行なった。測点間隔は $x, y$ 軸方向にそれぞれ $5 \times$ $5(\mathrm{~cm})$ のメッシュと，側壁から2 $(\mathrm{cm})$ 離れた箇所で $x$ 軸方 向に5(cm)間隔でとり，合計325点で測定した。

\section{3. 実験ケース}

前述した，青木らが明らかにした流速比 $v_{p} / v_{f}$ と遡上率 の関係と，導流壁の循環流抑制効果7),8) の適用範囲を広 げるために，主水路幅を $15(\mathrm{~cm})$ から $45(\mathrm{~cm})$ に広げた階段 式魚道を用いた，そして，呼び水および導流壁の効果 について検討を行なうため，表-1に示すケース（Run 11-A 5-2-A）で流量および導流壁の有無を系統的に変化 させ，水理量の測定および実魚を用いた挙動実験を行 なった。 なお，青木ら ${ }^{7), 8)}$ の用いた階段式魚道モデルの 主水路幅 $b_{m}$, 呼び水水路幅 $b_{p}$, 魚道幅 $b_{f}$ の比は, $b_{m}: b_{p}: b_{f}$ $=3: 1: 2$ であり, 幅30 $(\mathrm{cm})$ 水路を用いている. 本実験に用

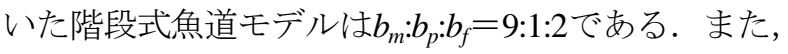
どちらの魚道モデルも魚道幅 $10(\mathrm{~cm})$, 呼び水水路幅 $5(\mathrm{~cm})$ と同值であり, 主水路幅の違いによる呼び水機能 の比較検討を行なった.

魚道下流域での洗掘の様子をみるため, Run 2-1-Aの 
河床条件を移動床としたもの（Run 2-1-B）を基本とし， 導流壁無し（Run 2-2-B），導流壁および呼び水水路無 し（Run 2-3-B）の条件で模型実験を行なった. また， 魚道下流端の隔壁部での水脈の剥離を再現するため,

Run 2-3-Bの条件で図-1 a) のpool-5を外し, 魚道下流端 の隔壁高10(cm)にし模型実験を行なった（Run 2-4-B）。

\section{4. 実験結果}

\section{（1）呼び水効果および導流壁の機能の検討}

青木らの遡上率の定義8)を用い遡上率 $R_{r}$ を求めた.

$$
R_{r}=\frac{F_{C}}{F_{T}}
$$

$F_{C}$ : 遡上に成功した魚の個体数, $F_{T}$ : 実験に使用した 魚の個体数である.

ここで，図-2に導流壁の有無と遡上率の関係を示す． 導流壁のない場合に比へ，導流壁を設けたRun 2-1-A,

Run 4-1-A，Run 5-1-Aは遡上率がそれぞれ2.0，1.8，4.9 倍に増えている. 図-3 a) b) に示寸魚道下流域の流速 ベクトル図を見てみると, 導流壁を設けることで魚道 下流域での循環流の発生を抑制していることがわかる

（図-3 a) 破線○部）。青木らの示した「呼び水水路と 主水路間に導流壁を設けることで，循環流の発生を抑 制し，呼び水の集魚効果を増進することができる．」 ${ }^{8)}$ と同様な結果を得ることができた.

図-4に, 呼び水流速 $v_{p}$ と魚道越流流速 $v_{f}$ の比 $v_{p} / v_{f}$ と遡 上率の関係を示す. Run 1-1-A 4-1-Aについては，青木 らの研究結果 ${ }^{8}$ と同様な傾向を示した. しかし, Run 51-Aについては異なる結果となった. これは, Run 5-1-A はRun 1-1-A 4-1-Aに比へ, 魚道下流域の流速が増加し ウグイの行動に影響を及ぼしているのではないかと考 えられる. ここで, 図-5にRun 4-1-AとRun 5-1-Aの魚道 下流域でのウグイの軌跡図を示寸，Run 4-1-Aでは，多 くの個体が左岸側を遡上し, $x=50 \sim 120(\mathrm{~cm})$, $y=35 \sim 45(\mathrm{~cm})$ の辺で定位した後に, さらに左岸側壁に そって魚道下流入口へと進入を試みていることがわ かった（図-5 a））。多くの個体が定位していた領域 の流速は，8 32(cm/s)であり，実験に使用したウグイの 体長BLの約1 4倍の流速であった（図-6 a)）。また, 魚道下流入口への遡上経路となる左岸側壁付近の流速 は, 魚道下流入口へ近づくにつれ上昇し， 28 48( $\mathrm{cm} / \mathrm{s})$ であった. ウグイの体長の2 4倍の值の流速は巡航速度 と呼ばれ, 長時間遊泳することが可能な流速と言われ ている.したがって，ウグイは魚道下流域において巡 航速度内の流速域で定位し，そこから魚道或いは呼び 水から出る速い流れを感知し, 走流性を発揮すること で魚道下流入口へ遡上していったといえる. 一方, Run 5-1-Aでは水路右岸側, $x=60 \sim 110(\mathrm{~cm}), y=0 \sim 25(\mathrm{~cm})$ の範 囲に多く定位していることが確認できた。 また，遡上

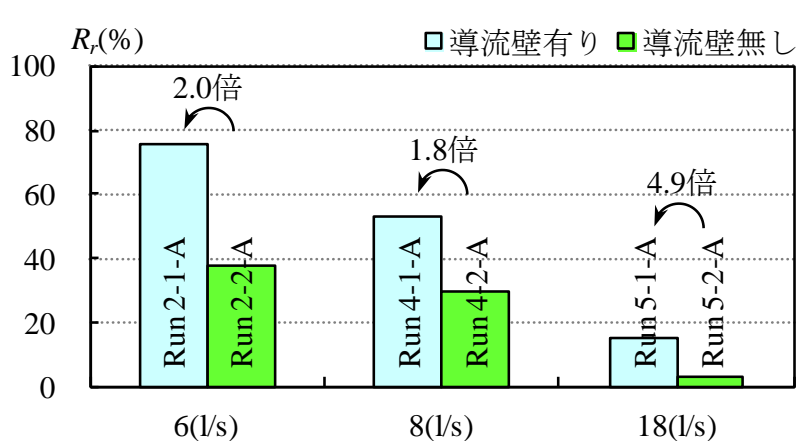

図-2 導流壁の有無と遡上率

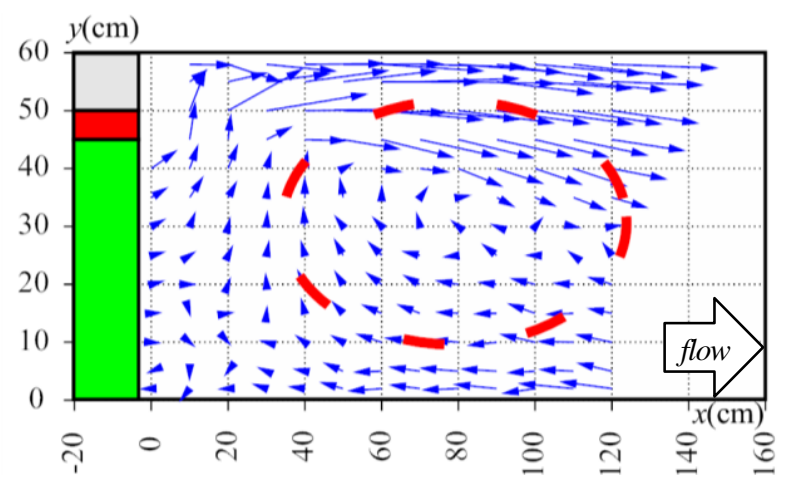

a) Run2-2-A

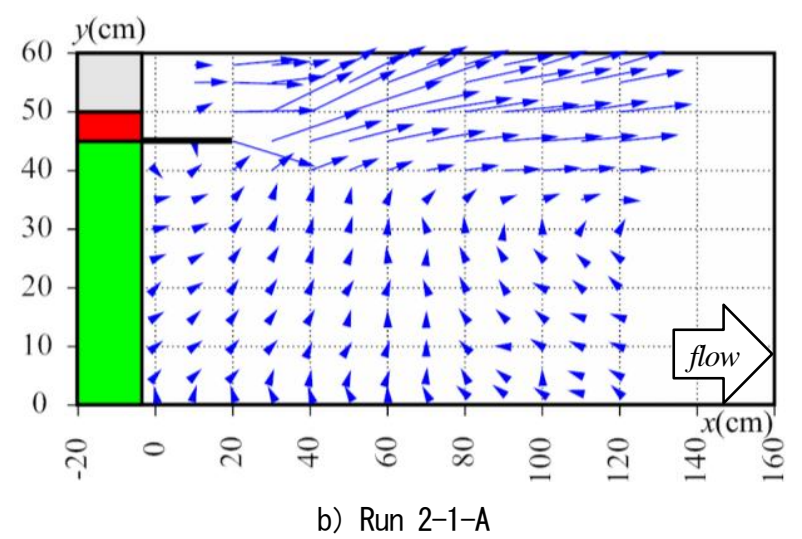

魚道，呼び水水路，“主水路，一導流壁

図-3 魚道下流域の流速ベクトル図

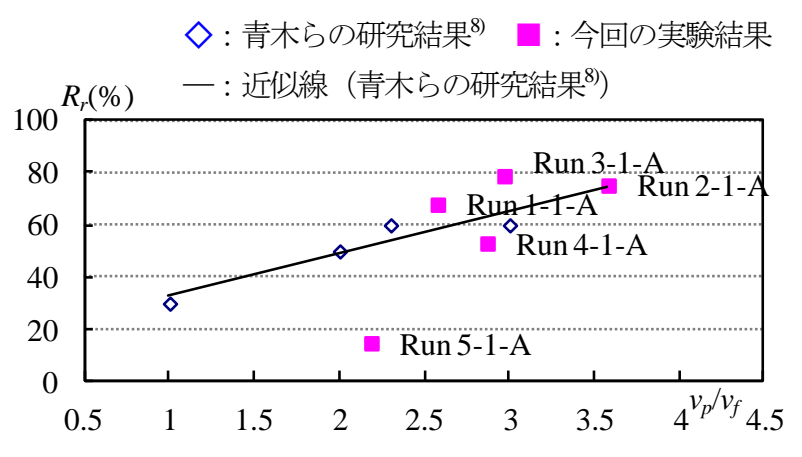

図-4 流速比 $v_{p} / v_{f}$ と遡上率の関係

を試みた個体は左岸側壁に沿って遡上を試みるが，魚 道下流入口まで辿りつけず下流へ押し流されてしまっ ていることが確認された（図-5 b) ) 。右岸側の定位 


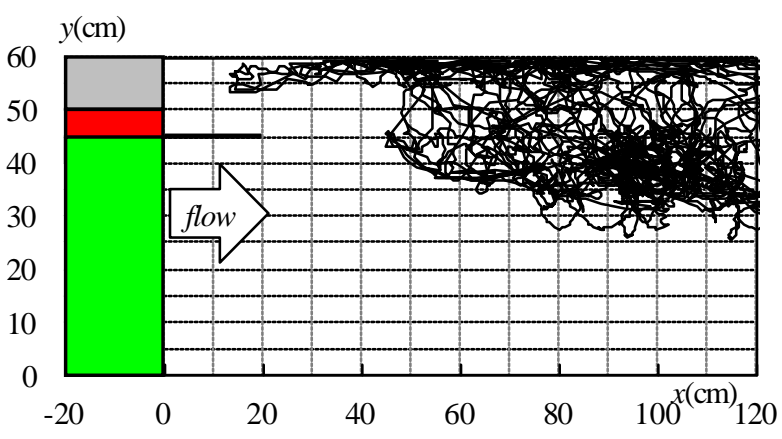

a) Run $4-1-A$

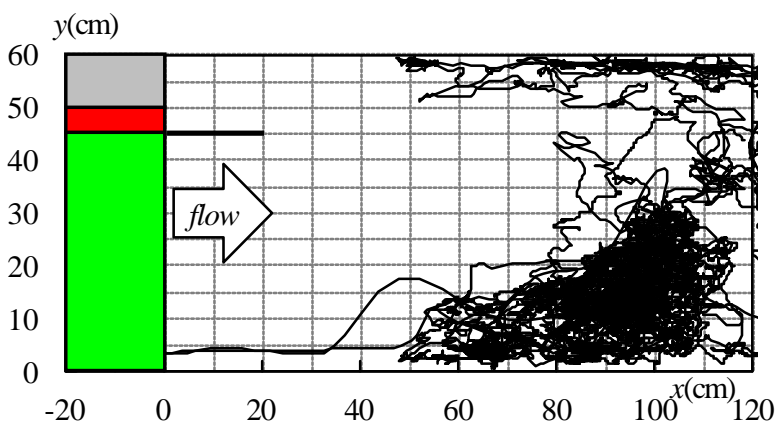

b) Run $5-1-A$

魚道, 口呼び水水路, 口主水路, 一導流壁

図-5＼cjkstart魚道下流域のウグイの軌跡図

がみられた領域の流速は体長 $B L$ の約 2 倍の流速であり

（図-6 b)），巡航速度に当てはまる。遡上経路と なっていた左岸側壁付近の流速は約65 90 $(\mathrm{cm} / \mathrm{s})$ であり， 体長BLの8 11倍の值であった. ウグイは速い流速の中 では下流へ押し流されないように突進速度で遊泳する。 その突進速度は体長の10倍以上だが，1 5秒間しか持続 しないとされている11). 泉らのスタミナトンネルを用い た遊泳力に関する研究では ${ }^{9)}$, 管内流速が約 $100(\mathrm{~cm} / \mathrm{s})$ の 時の突進速度は8 15BL/sであった. 今回の実験で用いた 個体が15BL/sの突進速度で5秒間遊泳した場合, 遡上経 路である左岸側壁では8 11BL/sの流速であるため，相対 遊泳速度は4 7BL/sになり, その時の遊泳距離は 20 35 $(\mathrm{cm})$ 程度となる. 魚道直下流の流速は8 12BL/sで あり, $x=20 \sim 120(\mathrm{~cm})$ 付近までその流れが持続している. したがって, 魚道直下流では突進速度での遊泳が魚道 下流入口まで持続できず，遡上率の低下につながった。

\section{（2）移動床の実験}

図-7に, 通水 30 分経過後における最終河床形状の等 高線図を示す．呼び水水路および導流壁の無いRun 2-3B，Run 2-4-Bを比較してみると，Run 2-3-Bは洗掘が小 規模であったが，Run 2-4-Bは広範囲に洗掘が生じてい る. Run 2-3-BとRun 2-4-Bの河床から隔壁上端までの距 離は，それぞれ $2(\mathrm{~cm})$ と7 $(\mathrm{cm})$ である.したがって， Run2-4-Bでは隔壁からの落下流がRun 2-3-Bに比べ卓越 しているため, 河床洗掘が広範囲に広がったと考えら れる. 一方, Run 2-3-Bは魚道最下流のプール床が本川

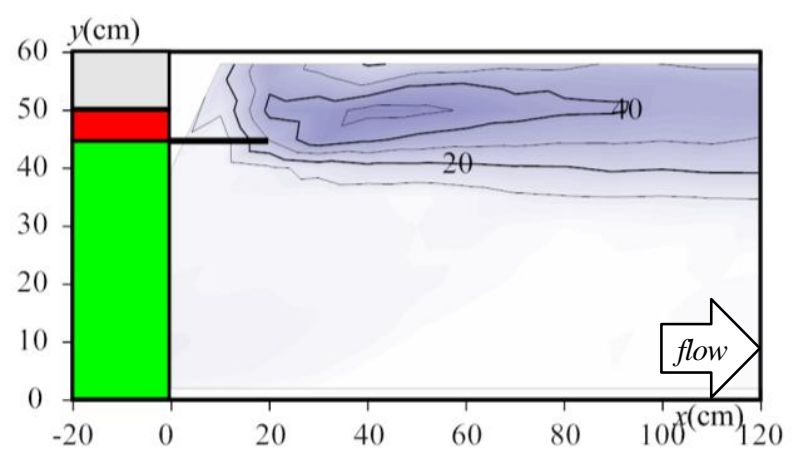

a) Run 4-1-A

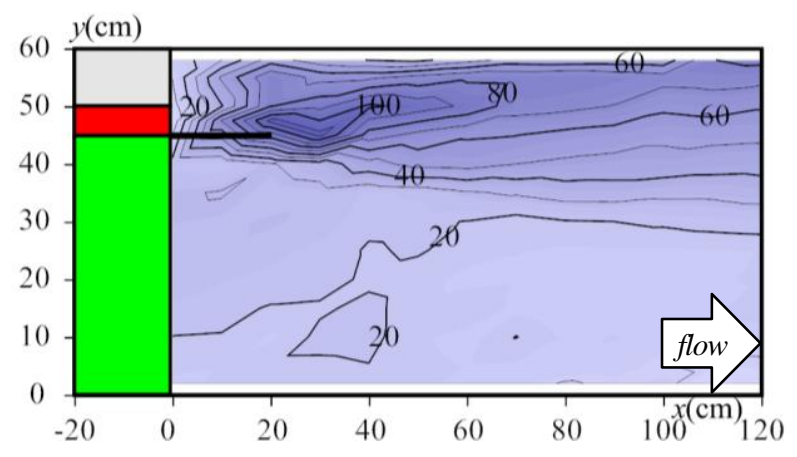

b) Run $5-1-A$

魚道, 口呼び水水路, 口主水路, 一導流壁

図-6 魚道下流域の流速コンター図

河床よりも低い位置にある，和田は，流量の変動や河 床低下に対応できるよう，魚道下流入口は最下流部の プールの隔壁上端を河床にまで潜入させることを提案 している ${ }^{1)}$. 今回の実験により，その提案が河床洗掘の 抑制にも効果があることが明らかになった.

これまでの研究で, 呼び水水路および導流壁を設け ることで魚道の集魚効果を上げることが可能であるこ とが明らかにした。しかし，移動床の実験の結果，呼 び氷が有るRun 2-1-B，Run 2-2-Bではどちらも河床の洗 掘が著しく, 呼び水の河床洗掘への影響が大きいこと がわかる，河床洗掘の進行は，隔壁部での落差の増大 や水脈の剥離を引き起こす．したがって，魚道への集 魚効果を目的とする呼び水水路の魚道への付加が，河 床洗掘をより進行させ，隔壁部での落差の増大や水脈 の剥離による遡上への障害が発生する可能性があるこ とが示唆された. 引き続き河床洗掘対策について研究 を行い, 呼び水による河床洗掘の問題点の解決法を明 らかにしていく必要がある.

\section{5. 数値解析}

魚道下流域の流れの変化と魚の行動予測を行なうこ とで, 階段式魚道の問題点に対する一つの解決策を見 出すことができると考えている.

模型実験によって, 魚道直下の局所洗掘に呼び水が 大きく起因することが分かった．これにより，魚の行 
動に対しても影響を及ぼすことが示唆された.

数值解析においても, 河床変動を考慮した流れの計 算と，それに対する魚の行動予測を行う必要があると 考えられる．そのためには先ず，固定床での流れの計 算が無理なく行えることが重要である. そこで本研究 では, 固定床での流れの計算モデルを構築した.

また, 魚の行動予測については, 著者らの既往の研 究でも提唱しているランダムウォークモデル212)用いる こととした．これは，「通常の流れ」に対する魚の行 動を対象にしているが，本研究では，呼び水水路や魚 道から流出する, いわゆる「速い流れ」を対象にし， 魚の行動予測を行った.

\section{（1）解析概要}

\section{a） 魚道下流域における流れの解析}

魚道下流域での流れを二次元的な流れとみなし，二 次元浅水流方程式および連続式を用いた．ここで，呼 び水流速 $v_{p}$ が主水路流速 $v_{m}$ よりも非常に大きい $\left(v_{m}<<v_{p}\right)$ ことから，複断面開水路における低水路と高水敷間ま たは河道内の樹木群内外の流れの境界部之同様に, 両 流体間で運動量交換が生じてしまうので，本研究では， 呼び水と主水路間の流孔の境界部での流体混合を考慮

し, 干渉によるせん断力項を考慮している8).

\section{b） 魚道下流域における魚の行動解析}

魚の遊泳行動は，水理条件や環境条件に左右される が，微小時間における移動は，本質的にランダムな動 きと考えられる．そこで，魚の行動追跡には，ランダ ムウォーク法を使用した ${ }^{10)}$. 具体的には, ある地点にい る仮想魚が次の瞬間に移動する方向をランダムに選択 させ，移動速度をその場の水理量（流速 $u, v)$ にあわせ， 変化させるものとした. 本研究では, 線形合同法によ り得られる乱数列 $Z=\left(z_{0} \ldots z_{n}\right)$ を使用した. 仮想魚の存在 個所は，次式により求めることができる.

$$
\left.\begin{array}{l}
X_{n}=\alpha \cdot \beta \cdot \gamma \cdot \Delta t\left(U_{m}-U\right) \cos \theta_{n}+X_{n-1} \\
Y_{n}=\alpha \cdot \beta \cdot \gamma \cdot \Delta t\left(U_{m}-U\right) \sin \theta_{n}+Y_{n-1}
\end{array}\right\}
$$

ここに, $X_{n}, Y_{n}$ : 現時刻に仮想魚が存在している箇所のx, y座標， $\alpha$ : 走流性を表寸係数， $\beta$ : 壁に反応を示寸係数, $\gamma$ : 構造物に反応を示寸係数, $U_{m}$ : 仮想魚の遊泳速度 $(\mathrm{m} / \mathrm{s}), U=\sqrt{u^{2}+v^{2}}:$ その場の流速值 $(\mathrm{m} / \mathrm{s})$ である. なお, $U_{m}, U$ Uスカラー量で与えており，Uは見かけの流速で あり，仮想魚の遊泳行動に対する抵抗とみなしている. $X_{n-1}, Y_{n-1}$ : 前時刻に仮想魚が存在していた箇所の $x, y$ 座標 である. $\theta_{n}$ は魚の移動方向とx座標とのな寸角度であり，

$$
\theta_{n}=2 \pi z_{n}
$$

であり, $0 \leq \theta_{n} \leq 2 \pi$ の範囲で与えられる.

なお，青木らは構造物に反応を示寸係数 $\gamma$ を $0 \leq \gamma \leq 1$ の範囲で与えている ${ }^{8)}$. 魚道は構造物であるため, $\gamma$ を考 慮する必要があるが，ここでは先ず，魚道の呼び水が つくり出寸流れと魚の行動のみに着目しているため, 構造物に反応を示寸係数㫲考慮しないことにした.

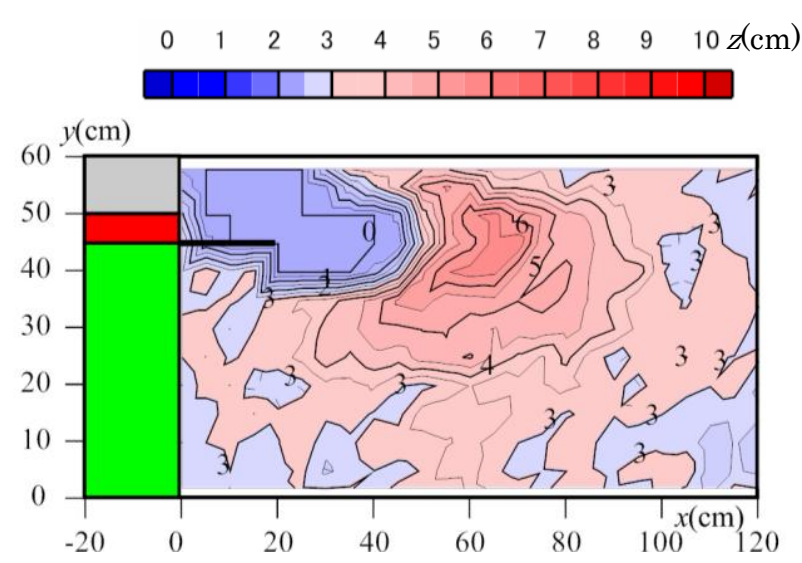

a) Run $2-1-B$

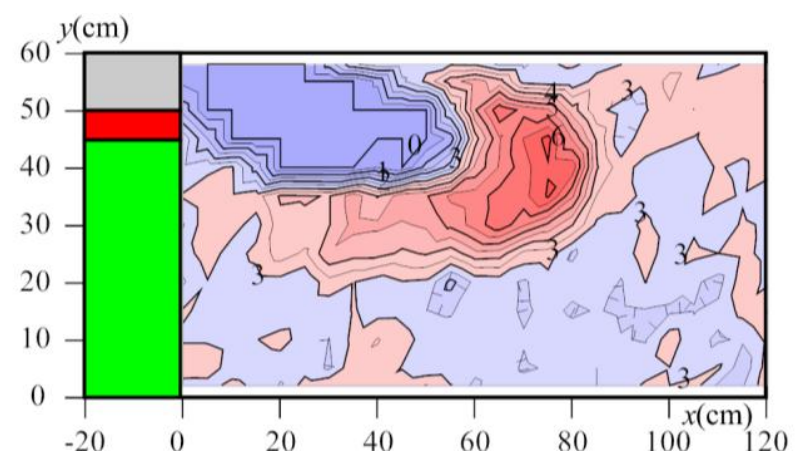

b) Run 2-2-B

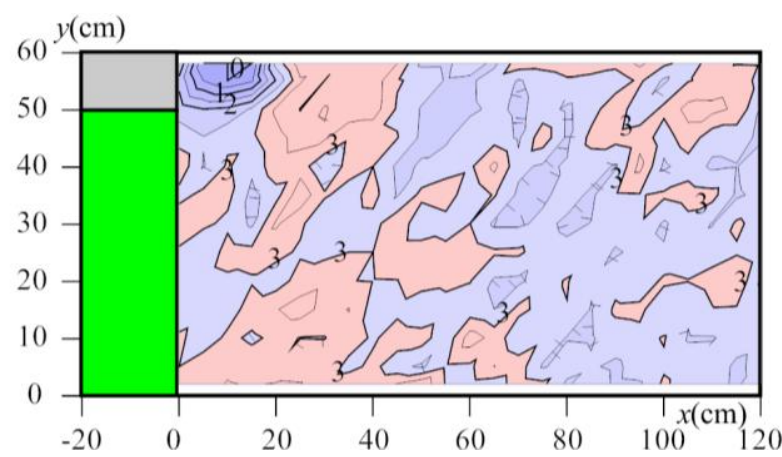

c) Run 2-3-B

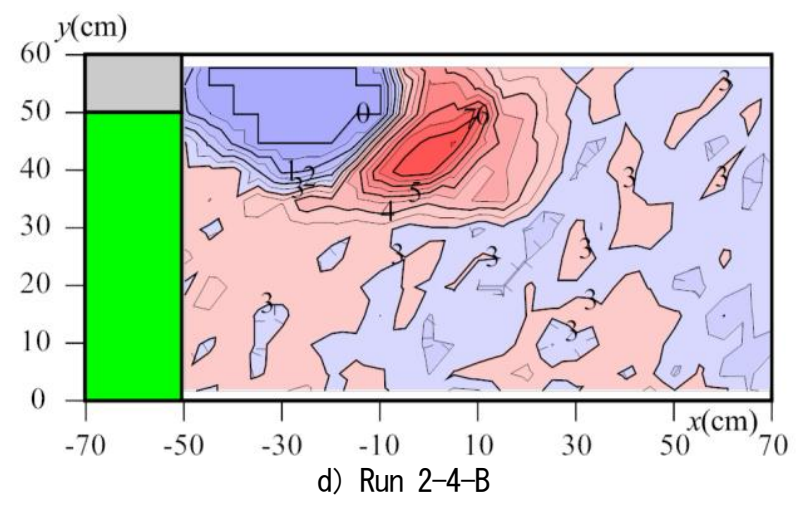

魚道, 口呼び水水路, 口主水路, 一導流壁 図-7 最終河床形状の等高線図

走流性を表わす係数 $\alpha$ および壁に反応を示す係数 $\beta$ の 詳細は，既往の報告に示されている13).

\section{(2) 解析結果}

a）流れの解析結果 


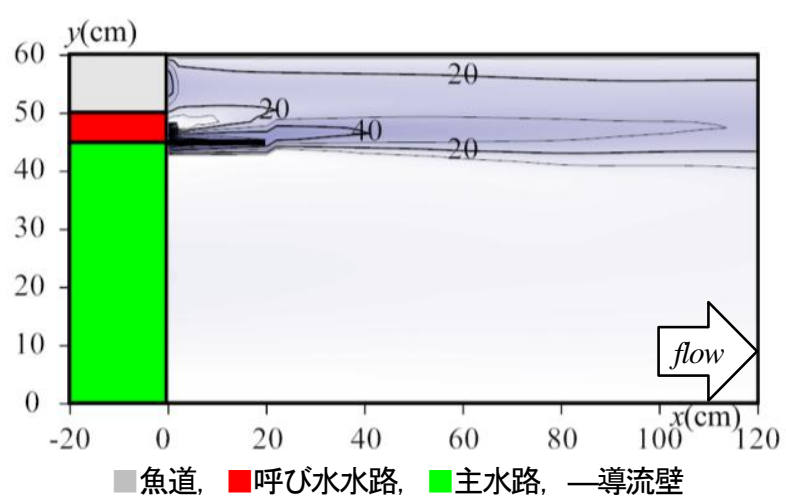

図-8 流速の数值解析結果

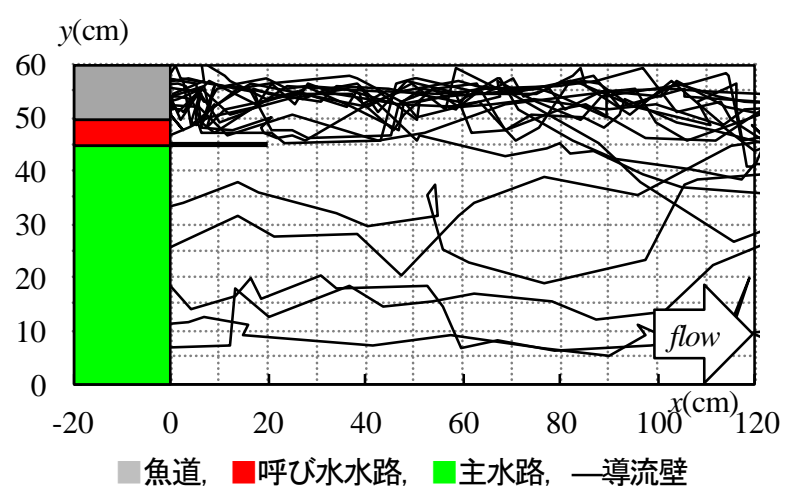

図 -9 魚の挙動の数值解析結果

図-8に, Run 4-1-Aにおける流れの解析結果を示寸. 実験結果（図-6 a））と比べ，呼び水の拡がり方や魚 道延長上の流速, 主水路での循環流の生起など，概ね 良好に再現できている.

\section{b）魚の行動解析結果}

図-9に, Run 4-1-Aにおける魚の解析結果を示寸．仮 想魚が主水路側から魚道下流入口へ向かって遡上寸る 様を再現できている. 魚の行動特性をさらに詳細に検 討し，モデルに反映させることで，より精度の高いラ ンダムウォークモデルを構築できるので, 魚の行動予 測を精度良く行える. その結果, 魚道に対する問題点 を解決する一つの方法を確立できると考えている.

\section{6. おわりに}

規模の異なる2種類の階段式魚道を用い，呼び水のつ くり出寸魚道下流域の流れとウグイの行動特性につい て, 模型実験および数值解析により, 更に詳細な検討 を行った。 また, 呼び水による魚道下流域の河床洗掘 への影響について, 移動床を用いて実験的に調査を 行った. これらにより得られた知見を以下に示す.

(1) 模型規模の異なる階段式魚道においても, 導流壁 の循環流抑制効果を確認できた。

(2) 流速比 $v_{p} / v_{f}$ と遡上率の関係は, 青木らの研究結果 ${ }^{8)}$ と同様な傾向を示し， $v_{p} / v_{f}=3.58$ まで適応すること が可能な事を明らかにした。
（3）魚道直下流の魚が突進速度で突破することのでき ない領域では，青木らによる流速比 $v_{p} / v_{f}$ と遡上率の 関係 ${ }^{8}$ は当てはまらないこともある。今回の場合は, 8 12BL/sの流速が縦断方向に20 35(cm)の範囲であ る場合に魚道下流入口への進入が困難になる.

（4）魚道下流入口の集魚効果を増進する呼び水によっ て, 河床の洗掘が進行する恐れがあることが分 かった，それに対しては，プールを増設し落差を 小さくする方法が有効である.

(5) 二次元浅水流モデルとランダムウォークを用いる ことにより，呼び水効果は十分に検討することが できる.

\section{参考文献}

1) 和田吉弘 : 言いたい放題魚道見聞録, pp.62-63, 山海堂, 2003

2) 国土交通省水管理·国土保全局HP : 魚がのぼりやすい川づ くりの手引き, http://www.mlit.go.jp/river/shishin_guideline/ kankyo/kankyou/sakana_tebiki/pdf/print.pdf

3）浦 勝, 山口秀和, 鬼束幸樹, 秋山壽一郎 : 水位落差の大 きな魚道の流況改善について, 水工学論文集, 第47巻, pp.769-774, 2003

4) 前川勝朗, 大久保博, 大石幸司 : 棚田式魚道工における下 流部の洗掘について, 農業土木学会全国大会講演要旨集, pp.668-669, 2004

5) 中村俊六 : 魚道のはなし, pp.2,92, 山海堂, 1995

6) 広瀬利雄, 中村俊六 : 魚道の設計, p.255, 山海堂, 1991

7) 青木宗之, 福井吉孝, 小原 誠, 染井香栄 : 階段式魚道の 呼び水がつくり出す流れとそれに対する魚の行動，環境シ ステム論文集，Vol.36，pp.457-465，2008

8）青木宗之, 吉野 隆, 福井吉孝: 呼び水式魚道における流 れとそれに対する魚の挙動，ながれ，第28巻，pp.485-494， 2009

9）泉 完, 山本泰之, 神山公平: 高速流条件における現地の スタミナトンネルを用いたウグイの突進速度, 農業農村工 学会全国大会講演要旨集, pp.552-553，2007

10) 高水克哉, 栗原朋之, 青木宗之, 内山文哉, 福井吉孝: 杭 水制内外の流れと魚の挙動, 水工学論文集, 第51巻, pp.1273-1278, 2007

11) Blaxter, J.H.S : Swimming Speeds of Fish, proceedings of the FAO Conference on Fish Behavior in relation to Fishing Techniques and Tactics, in Bergen, Norway, pp.69-100, 1967

12) 関谷 明, 福井吉孝, 下村 充, 打田 剛: 魚類の迷入と その防止法，土木学会論文集，No.782/ $/$-70, pp.81-91, 2005

13）青木宗之, 福井吉孝: 魚道下流域での流れと魚の行動, 土 木学会関東支部第37回技術研究発表会，II-35，2010

(2011. 9. 30受付) 